\title{
Konsepsi Kebenaran dalam Penyelidikan Saintifik: Analisis Pemikiran Ibn al-Haytham
}

\author{
Mohd Syahmir Alias \\ Universiti Sains Malaysia, msa14_soc012@student.usm.my
}

\begin{abstract}
Abstrak
Ibn al-Haytham terkenal melalui sumbangannya dalam bidang optik dengan penghasilan magnum opusnya iaitu Kitāb al-Manāẓir. Disamping teori-teori optik yang diperkenalkan oleh beliau, kajiannya turut mengemukakan satu perkaedahan penyelidikan yang sistematik dikenali sebagai kaedah saintifik. Malah Ibn al-Haytham menegaskan bahawa nilai kebenaran sangat penting dalam penyelidikannya. Persoalannya, apakah pandangan beliau terhadap kebenaran dalam melakukan penyelidikan saintifik? Adakah konsepsi kebenaran Ibn al-Haytham ini mematuhi falsafah penyelidikan Islam? Hal ini kerana, terdapat pelbagai pandangan terhadap kebenaran dalam penyelidikan saintifik berdasarkan falsafah Barat yang bertentangan dengan akidah Islam. Justeru, makalah ini akan mengenal pasti dan menganalisis konsepsi kebenaran dalam penyelidikan saintifik Ibn al-Haytham secara komprehensif. Bagi memastikan tujuan analisis kandungan terhadap Kitāb al-Manāzir ini tercapai, data dikumpulkan juga daripada penulisan-penulisan Ibn alHaytham yang lain. Perbincangan dalam makalah ini dibahagikan kepada dua bahagian iaitu pertama, pandangan Ibn al-Haytham terhadap kebenaran dalam penyelidikan saintifik; dan kedua, analisis dari perspektif falsafah penyelidikan Islam. Hasilnya, makalah ini menemui enam konsepsi kebenaran yang dipegang oleh Ibn al-Haytham. Pertama, kebenaran bersifat tungal; kedua, kebenaran adalah petunjuk yang boleh bermula dengan sikap skeptik; ketiga, kebenaran menolak sifat taklid atau autoritarianisme; keempat, kebenaran bersifat objektif; kelima, pembuktian matematik dapat mencapai kebenaran; dan keenam, kebenaran berasaskan sunnat Allāh. Keenam-enam pandangan Ibn alHaytham terhadap kebenaran dalam kaedah saintifik ini sepadan dengan paradigma tauhid sekali gus selaras dengan falsafah penyelidikan Islam.
\end{abstract}

Kata kunci: konsepsi kebenaran, Ibn al-Haytham, penyelidikan saintifik, falsafah penyelidikan Islam, pemikiran Islam

Conceptions of Truth in Scientific Research: Analysis on the Thoughts of Ibn al-Haytham

\section{Abstract}

Ibn al-Haytham (Alhazen) was known through his contributions in the field of optics and his magnum opus, Kitāb al-Manāzir. Beside of the 
optical theories introduced by him, his study also set out a systematic research methodology known as the scientific method. In fact, Ibn alHaytham pointed out that the truth value is very important in his research. What is his view regarding the truth in doing scientific research? Is Ibn al-Haytham's conceptions of truth conform with the philosophy of Islamic research? Moreover, there are different views on the truth in scientific research based on Western philosophies which are contrary to the Islamic faith. Thus, this paper seeks to identify and analyze Ibn al-Haytham's conception of truth in scientific research comprehensively. To ensure that the purpose of content analysis in Kitāb al-Manāzir is achieved, the data is collected from any other of Ibn alHaytham's works. The discussion in this paper is divided into two parts: first, Ibn al-Haytham's conceptions of truth in scientific research; and second, an analysis from the perspective of the philosophy of Islamic research. As a result, this paper found six conceptions of truth which is hold by Ibn al-Haytham. First, the singularity of truth; second, truth is a guidance which may begin with scepticism; third, truth must be antiauthoritarianism; fourth, truth must be objective; fifth, proof of mathematics can reach the truth; and sixth, truth are based on the law of God (sunnat Allāh). These six views of Ibn al-Haytham regarding the truth in scientific method are based on the concept of oneness of God (tawhìd), which are consistent with the philosophy of Islamic research.

Keywords: conceptions of truth, Ibn al-Haytham (Alhazen), scientific research, philosophy of Islamic research, Islamic thought

\section{Pendahuluan}

Dari perspektif Islam, kebenaran adalah petunjuk yang diberikan oleh Allah SWT kepada manusia. ${ }^{1}$ Hal ini kerana salah satu daripada nama-nama Allah SWT ialah al-Haq yang membawa maksud yang Maha Benar. ${ }^{2}$ Oleh yang demikian, kebenaran merupakan suatu konsepsi penting yang wujud dalam pemikiran manusia. Hal ini kerana kebenaran melibatkan keyakinan objektif dan subjektif terhadap sesuatu hakikat. ${ }^{3}$ Terdapat tiga darjah atau

1 Osman Bakar, Tawhid and Science: Essays on the History and Philosophy of Islamic Science (Pulau Pinang: Secretariat for Islamic Philosophy and Science, 1991), 6.

2 Talib Samat, 99 Nama Allah Tersohor: Khasiat dan Cara Beramal (Kuala Lumpur: Utusan Publications and Distributors, 2004), 225.

3 Syed Muhammad Naquib al-Attas, Islam and the Philosophy of Science (Kuala Lumpur: International Institute of Islamic Thought and Civilization, 1989), 2. 
tahap dalam capaian keyakinan dari sudut pandang Islam. Pertama, 'ilm al-yaqīn (keyakinan berasaskan ilmu); kedua, 'ayn al-yaqin (keyakinan berasaskan kontemplasi dan pemerhatian); dan ketiga, haqq al-yaqin (keyakinan yang sebenar-benarnya) yang merupakan tahap keyakinan tertinggi. Menurut Seyyed Hossein Nasr, ketiga-tiga peringkat keyakinan (certitude) ini diekstrak daripada terminologi dalam ayat-ayat al-Qur'an. ${ }^{4}$ Justeru, berdasarkan ketiga-tiga peringkat keyakinan ini, penyelidikan menjadi medium penting untuk mendapatkan sesuatu kebenaran.

Dalam konteks kini, pemikiran berpaksikan perkaedahan saintifik (scientific methodology) secara jelas mendominasi cara berfikir untuk mencapai sesuatu kebenaran yang dapat diterima oleh masyarakat sejagat. ${ }^{5}$ Melalui metodologi ini, khazanah pengetahuan yang dikenali sebagai sains ${ }^{6}$ dapat dikumpulkan. ${ }^{7}$ Walau bagaimanapun, sains dan perkaedahan saintifik ini pada hakikatnya berasaskan pandangan alam ataupun tasawur Barat. ${ }^{8}$ Tasawur mereka berpaksikan prinsip hukum tabii (law of nature) dengan penghujahan sebab-akibat (causality) sahaja. ${ }^{9}$ Selain itu, perkaedahan saintifik yang mementingkan kaedah uji kaji dan

4 Secara analoginya, 'ilm al-yaqin adalah keyakinan berasaskan pengetahuan seseorang mengenai api, 'ayn al-yaqin pula ialah keyakinan dengan melihat sendiri api tersebut, manakala haqq al-yaqin dicapai apabila seseorang itu dibinasakan oleh api. Lihat Seyyed Hossein Nasr, Knowledge and the Sacred (Albany: State University of New York, 1989), 325.

5 Selamat Amir, Mohd Murshidi Mohd Noor \& Ahmad Bazli Ahmad Hilmi, “Aplikasi Elemen Saintifik dalam Tafsir al-Qur'an: Satu Pengamatan Awal Terhadap Manhaj Zaghlūl el-Najjār dalam Tafsīr al-Ayah al-Kawnīyyah fi alQur'ān al-Karīm," Al-Bayan 10, no. 2 (2012): 52.

6 Sains dari perspektif akademik merangkumi bidang sains kemasyarakatan atau social sciences dan juga sains tabii atau natural sciences. Lihat Ahmad Mahdzan Ayob, Kaedah Penyelidikan Sosioekonomi (Kuala Lumpur: Dewan Bahasa dan Pustaka, 2007), 6.

7 Ahmad Mahdzan Ayob, Kaedah Penyelidikan Sosioekonomi, 9.

8 Sulaiman Noordin, "Sains, Falsafah dan Islam", dalam Siri Wacana Sejarah dan Falsafah Sains Jilid I, ed. Mohd Yusof Othman (Kuala Lumpur: Dewan Bahasa dan Pustaka, 1992), 25; Muhammad Syukri Salleh, "Kaedah Penyelidikan Berteraskan Islam: Keperluan, Kedudukan dan Hala Tuju," Pemikir, no. 54 (2008): 145.

9 William Lawrence Neuman, Social Research Methods, Qualitative and Quantitative Approaches Seventh Edition (Boston: Pearson Education, 2011), 96. 
bukti empirikal pula menjadi alasan bagi sesetengah ahli sains Barat menyerang perkara-perkara yang bersifat ghaib. ${ }^{10}$ Malah, terdapat tiga perbezaan pendapat dalam kalangan cendekiawan Barat mengenai kebenaran ilmu yang diperoleh melalui penyelidikan saintifik. Pertama, melalui penyelidikan saintifik sahaja kebenaran yang mutlak dapat diperoleh; kedua, ia membawa kepada kebenaran nisbi (relatif); dan ketiga, ia tidak membawa kebenaran tetapi boleh dibuktikan kesalahannya. ${ }^{11}$ Persoalannya, apakah pula pandangan kebenaran penyelidikan saintifik oleh sarjana Muslim dan falsafah penyelidikan Islam?.

Oleh itu, makalah ini meneliti konsepsi kebenaran dari perspektif Ibn al-Haytham. Hal ini kerana, beliau merupakan cendekiawan Muslim yang dikenali dengan pembinaan metodologi penyelidikan saintifik melalui penulisan Kitāb al-Manāzir (Buku Optik). ${ }^{12}$ Malah pemikiran saintifik beliau ini mempengaruhi sarjana-sarjana Barat pada zaman berikutnya seperti Frederick dari Fribourg, Johannes Kepler dan René Descartes. ${ }^{13}$ Sekiranya pemikiran saintifik beliau berjaya mempengaruhi cendekiawan Barat, adakah pandangan beliau terhadap kebenaran dalam melakukan penyelidikan saintifik mempunyai persamaan dengan cendekiawan Barat? Bagi menjawab persoalan ini, perbincangan dalam makalah ini terbahagi kepada dua bahagian. Pertama, pengenalpastian konsepsi kebenaran dalam penyelidikan saintifik Ibn al-Haytham; dan kedua, analisis dari perspektif falsafah penyelidikan Islam.

${ }^{10}$ Shaharir Mohamad Zain, Pengenalan Sejarah dan Falsafah Sains (Bangi: Penerbit Universiti Kebangsaan Malaysia, 2000), 69.

11 Mat Rofa Ismail, Falsafah Sains Pendekatan Kualitatif (Kuala Lumpur: Dewan Bahasa dan Pustaka, 2006), 152.

12 Alan Kennedy, Ralph Radach, Dieter Heller dan Joel Pynte, Reading as a Perceptual Process (Oxford: Elsevier Science, 2000), Rosanna Gorini, "AlHaytham the Man of Experience: First Steps in the Science of Vision," Journal of the International Society for the History of Islamic Medicine 2, no. 4 (2003): 55.

13 Roshdi Rashed, "A Polymath in the $10^{\text {th }}$ Century," Science 297 (2002): 773; Mat Rofa Ismail, Falsafah Sains Pendekatan Kualitatif, 104. 


\section{Konsepsi Kebenaran Ibn al-Haytham dalam Penyelidikan Saintifik}

Daripada penelitian yang dilakukan kepada data sekunder iaitu biografi yang ditulis oleh Ibn al-Haytham sendiri dan disalin

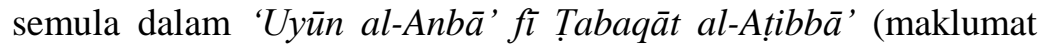
penting tentang kategori ahli perubatan), karya-karya beliau dan petikan kata Ibn al-Haytham daripada kajian-kajian oleh pengkaji terdahulu, makalah ini dapat mengenal pasti enam konsepsi beliau terhadap nilai kebenaran dalam penyelidikan saintifik. Keenamenam pandangan tersebut akan dibincangkan secara terperinci dalam subtopik-subtopik berikut.

\section{1) Kebenaran Bersifat Tunggal}

Berdasarkan biografi ringkas yang ditulis sendiri oleh Ibn alHaytham, kehidupan beliau pada usia mudanya dipengaruhi oleh konflik percanggahan pendapat dan pemecahan kelompokkelompok (firqah) mazhab akidah di Basrah. ${ }^{14}$ Antara mazhab yang berbeza pendapat itu ialah Ash'ariyyah, ${ }^{15} \mathrm{Shi}^{6} \mathrm{ah}^{16}$ dan Mu'tazilah. ${ }^{17}$ Pada kesempatan itu, Ibn al-Haytham mengambil inisiatif untuk menyelidiki dan mencari titik persamaan antara pegangan $\left(i^{\prime} t i q \bar{a} d\right)$ semua mazhab akidah tersebut. ${ }^{18}$ Daripada dapatan kajiannya, beliau berpandangan bahawa perbezaan antara mazhab-mazhab teologi bukan kerana kepelbagaian kebenaran itu,

14 Ibn Abī Ușaybi'ah, 'Uyūn al-Anbā' fì Țabaqāt al-Aṭibbā' (Beirut: Dār Maktabah al-Ḥayāh, 1965), 552.

15 Ash'ariyyah merupakan mazhab akidah yang menggunakan kaedah ahli fuqaha dan ahli Hadith. Lihat Muhammad Abu Zahrah, Aliran Politik dan 'Aqidah dalam Islam, terj. Abd. Rahman Dahlan dan Ahmad Qarib (Jakarta: Logos, 1996), 34.

${ }^{16}$ Shi'ah merupakan mazhab akidah yang pada awalnya bermula dengan pendekatan politik. Mazhab ini tampil pada penghujung zaman pemerintahn Khalifah 'Uthman bin 'Affan dan berkembang sewaktu pemerintahan Khalifah 'Ali bin Abi Talib. Muhammad Abu Zahrah, Aliran Politik dan 'Aqidah dalam Islam, 34.

$17 \mathrm{Mu}$ 'tazilah merupakan mazhab akidah yang memperincikan persoalanpersoalan teologi secara mendalam dan menggunakan kaedah falsafah iaitu banyak berdalilkan akal. Mazhab ini juga digelar "kaum rasionalis Islam". Lihat Harun Nasution, Teologi Islam: Aliran-aliran Sejarah Analisa Perbandingan (Jakarta: Penerbit Universits Indonesia, 1983), 38.

18 Bradley Steffens, Ibn al-Haytham: First Scientist (Greensboro: N. C. Morgan Reynolds, 2007), 31-32. 
tetapi disebabkan oleh kepelbagaian kaedah untuk mencari kebenaran. ${ }^{19}$

Dalam perkataan lain, kajian Ibn al-Haytham memberikan kesimpulan bahawa kebenaran seharusnya wujud sebagai satu entiti yang tunggal sifatnya. Pandangan ini dilontarkan oleh beliau seperti petikan berikut:

"Saya mula merasakan terdapat keraguan tentang semua kepercayaan ini dan saya sangat yakin bahawa kebenaran hanya satu dan bahawasanya perbezaan yang timbul adalah kerana perbezaan pendapat dan pendekatan dalam mencapai kebenaran." 20

Menurut Heinen, ${ }^{21}$ sekiranya kenyataan beliau ini ditafsirkan dalam kerangka teologi yang sempit, maka kesimpulan yang dapat dibuat adalah beliau telah terpesong akidahnya daripada ajaran Islam. Pentafsiran seperti ini hanya akan berlaku kepada golongan yang menolak kepercayaan agama, seperti golongan ateisme, tanpa mempertimbangkan penulisan-penulisan beliau yang lain. Walau bagaimanapun, perkara sebenar yang ingin disampaikan oleh Ibn al-Haytham ini adalah semata-mata kerana prinsipnya yang berpegang pada ketunggalan kebenaran yang ingin diperoleh. Oleh yang demikian, beliau berusaha untuk mencari pendekatan terbaik untuk mencapai hasratnya itu. Ibn al-Haytham selanjutnya menegaskan:

"Saya menyelidiki kepelbagaian pandangan dan pegangan dalam ilmu keagamaan. Maka saya tidak mendapati ianya (penyelidikan itu) sia-sia. Namun saya masih tidak menemui kaedah yang diyakini untuk menuju kebenaran.,22

Walaupun Ibn al-Haytham mengakui kepelbagaian perkaedahan, namun setelah itu, beliau menyedari bahawa

19 Mohammed Abed al-Jabri, The Formation of Arab Reason: Text, Tradition and the Construction of Modernity in the Arab World (New York: I.B Tauris \& Co., 2011), 436.

${ }^{20}$ Dipetik daripada Ibn Abī Ușaybi'ah, 'Uyūn al-Anbā' fì Tabaqāt al-Ațibbā', 552.

21 Anton M. Heinen, "Al-Biruni and al-Haytham: A Comparative Study of Scientific Method", dalam Al-Bīrūnī Commemorative Volume: Proceedings of the International Congress Held in Pakistan on the Occasion of Millenary of Abū Rā̄hān Muhammad ibn Ahmad al-Bīrūn̄̄ ed. Hakim Mohammed Said (Karachi: Hamdard Academy, 1973), 503.

22 Dipetik daripada Ibn Abī Ușaybi'ah, 'Uyūn al-Anbā' fì Ṭabaqāt al-Ațibbā', 552. 
kajiannya perlu menggunakan suatu kaedah yang berasaskan pancaindera dan akal untuk mencapai kebenaran. Kaedah tersebut dikenali sebagai kaedah saintifik pada hari ini. ${ }^{23}$ Hal ini juga merupakan rentetan daripada kenyataan beliau seperti berikut:

"Pada pandangan saya, sesuatu kebenaran itu tidak dapat dicapai melainkan pandangan tersebut berunsurkan perkaraperkara inderawi dan bentuknya berasaskan penaakulan minda." 24

\section{2) Kebenaran adalah Petunjuk yang Boleh Datang daripada Keraguan}

Rentetan daripada itu, Ibn al-Haytham banyak mendalami kajiankajian yang pernah dilakukan oleh cendekiawan Yunani silam berkenaan alam tabii. ${ }^{25}$ Walau bagaimanapun, Ibn al-Haytham dalam sebuah karyanya bertajuk Maqālah fì al-Shukūk 'alā Bațlamyūs (makalah berkenaan keraguan terhadap Ptolemy) menyatakan:

"Pencari kebenaran bukanlah seorang yang mengkaji penulisan-penulisan lampau dan mengikut sifat aslinya (iaitu) meletakkan kepercayaannya kepada (penulisan-penulisan) tersebut, akan tetapi dia seorang yang meragui keyakinannya terhadap mereka dan mempersoalkan perkara yang didapatinya daripada mereka, mengajukan hujah serta menampilkannya (dengan demonstrasi).'

Petikan ini merupakan sebahagian daripada sikap skeptik yang wujud dalam konsepsi kebenaran Ibn al-Haytham. Malah, beliau juga dengan berani menyatakan kesalahan pengkaji terdahulu. Seterusnya, beliau menjelaskan kesalahan pengkaji tersebut dengan membuktikan pernyataan beliau sendiri. ${ }^{27}$ Dengan nada yang lebih lantang, beliau menegaskan dalam Maqālah fi

23 Mat Rofa Ismail, Falsafah Sains Pendekatan Kualitatif, 103.

${ }^{24}$ Dipetik daripada Ibn Abī Ușaybi'ah, 'Uyūn al-Anbā' fì Tabaqāt al-Ațibbāa', 552.

25 Muhammad Saud, The Scientific Method of Ibn al-Haytham (Islamabad: Islamic Research Institute, 1990), 4.

26 Dipetik daripada Steffens, Ibn al-Haytham: First Scientist, 116.

27 George Saliba, Islamic Science and the Making of European Renaissance (Cambridge: The MIT Press, 2007), 240; Muhammad Saud, The Scientific Method of Ibn al-Haytham, 8. 
Kayfiyyat al-Iẓlāl (makalah berkenaan pembentukan bayangbayang):

"Kami menemui bahawa pengkaji-pengkaji yang membincangkan mengenai bayang-bayang mengguna pakai kaedah yang sama (untuk meneliti) semua jenis bayangbayang. Seterusnya, apabila kami mempertimbangkan kaedah tersebut, kami dapati bahawa kaedah itu tidak boleh dipercayai." $" 28$

Selain itu, petikan ini menunjukkan betapa isu kebolehpercayaan sangat penting dalam penyelidikannya. Hakikatnya, fasa keraguan yang dialami oleh Ibn al-Haytham ini juga pernah dialami oleh al-Ghazālī seperti yang dijelaskan dalam kitabnya, al-Munqidh min al-Dalāl (penyelamat daripada kesesatan). Menurut al-Ghazālī, kepelbagaian agama dan keimanan yang diwarisi secara taklid (mengikut tanpa penilaian) ini tidak membawa manusia kepada fitrah yang sebenar. ${ }^{29}$

\section{3) Kebenaran Tidak Dapat Dicapai dengan Taklid}

Bagi memastikan dirinya mengikuti fitrah yang benar dalam penyelidikan saintifik, Ibn al-Haytham menolak keautoritian sepenuhnya terhadap penyelidik-penyelidik sebelumnya. ${ }^{30}$ Sebagai contoh, berdasarkan sebuah karyanya iaitu Maqālah fi Harakat alQamar (makalah berkenaan pergerakan bulan), beliau mengkritik ilmuwan yang mengikut secara taklid pandangan cendekiawan Yunani silam seperti berikut:

"Telah jelas kepada saya daripada kenyataan Mawlāna alShaykh, sesungguhnya dia membenarkan perkataan Ptolemy dalam semua yang dikatakan tanpa bersandarkan pembuktian yang benar dan tidak sekali-kali pada pematahan hujah, bahkan ia hanyalah taklid semata-mata... Taklid bukanlah cara bagi para ahli matematik mempercayai pakar-pakar dalam bidang sains... Jelaslah bahawa Ptolemy telah

28 Muhammad Saud, The Scientific Method of Ibn al-Haytham, 8.

29 Al-Ghazālī, Penyelamat dari Kesesatan, terj. Abdulfatah Haron Ibrahim (Kuala Lumpur: Dewan Bahasa dan Pustaka, 1991), 5-6.

30 Muhammad Saud, The Scientific Method of Ibn al-Haytham, 7. 
melakukan banyak kesilapan dalam perenggan bukubukunya." 31

Berdasarkan petikan tersebut, terdapat tiga perkara yang ditekankan oleh Ibn al-Haytham. Pertama, bertaklid dalam hal-hal yang boleh diragukan tidak akan membawa penyelidikan saintifik kepada kebenaran; kedua, setiap pernyataan dalam sesebuah penyelidikan saintifik memerlukan pembuktian yang benar ataupun sekurang-kurangnya pengujian; dan ketiga, seseorang penyelidik lampau dalam kajian saintifik juga tidak dapat lari daripada melakukan kesilapan. Oleh sebab itu, beliau menegaskan bahawa taklid harus dihindari. Walau bagaimanapun, Ibn alHaytham menyedari bahawa autoriti hanya boleh diberikan kepada sabdaan Rasulullah SAW seperti yang dilakukan oleh pakar Hadith:

"Perkara ini merupakan iktikad ( $i$ 'tiqād) ahli Hadith kepada para nabi (anbiya $\bar{a})$, selawat dan salam ke atas mereka. Taklid bukanlah cara bagi para ahli matematik mempercayai pakarpakar dalam bidang sains." ${ }^{32}$

Hal ini kerana pada dasarnya, prinsip beliau yang mementingkan bukti dan sumber yang sahih turut menggambarkan prinsip yang dipegang oleh ahli Hadith dalam menentukan kesahan Hadith. ${ }^{33}$ Oleh yang demikian, kesahan sesuatu kebenaran dapat diperoleh sekiranya seseorang penyelidik mempunyai sikap objektif dalam penyelidikan dan tidak bertaklid semata-mata.

\section{4) Kebenaran Memerlukan Objektiviti}

Ketelitian Ibn al-Haytham dalam menjalankan kajian saintifiknya menonjolkan kredibiliti beliau sebagai seorang penyelidik yang sangat berpemikiran kritis. ${ }^{34}$ Bagi memastikan sama ada kajiankajian yang dilakukan oleh penyelidik lampau mempunyai nilai

31 Dipetik daripada Roshdi Rashed, "The Celestial Kinematics of Ibn alHaytham," 11.

32 Dipetik daripada Roshdi Rashed, "The Celestial Kinematics of Ibn alHaytham," 11.

33 Ziauddin Sardar, Hujah Sains Islam, terj. Abdul Latif Samian (Kuala Lumpur: Dewan Bahasa dan Pustaka, 1992), 31; Shahir Akram Hassan, Penerapan Kaedah Pengumpulan Hadith dalam Penyelidikan (Kuala Lumpur: Dewan Bahasa dan Pustaka, 2013), 42.

34 Sobhi Rayan, "Islamic Philosophy of Education," International Journal of Humanities and Social Science 2, no. 19 (2012): 150. 
kebenaran ataupun ia sekadar pendapat mereka semata-mata, beliau mengadili sesuatu perkara secara objektif (almawdu'iyyah). Beliau menyatakan dalam Kitāb al-Manāzair bahawa:

"Setelah kami melakukan penyelidikan dan penaakulan secara berperingkat-peringkat dan teratur, kritikan terhadap premis dan kesimpulan dibuat dengan berhati-hati; matlamat kami supaya setiap pengujian dan penyorotan terhadap sesuatu subjek dapat diadili, tidak mengikut prasangka serta mengambil kira perkara yang kami nilai dan kritik yakni yang dicari kebenarannya dan tidak terpengaruh dengan sesuatu pendapat." 35

Dengan penegasan yang beliau lakukan, jelaslah bahawa beliau menjalankan kajian saintifik agar maklumat atau data yang benar dapat diperoleh seterusnya beliau dapat menolak pandangan-pandangan yang tidak berasas. Selain itu, sikap tegas Ibn al-Haytham ini menggambarkan bahawa setiap kajian saintifik yang dilakukan perlulah mempunyai tujuan untuk memperoleh kebenaran dan tidak dipengaruhi oleh faktor-faktor lain. Dalam Maqālah fì al-Shukūk 'alā Bațlamyūs, beliau menyatakan:

"Sesuatu kebenaran itu dicari kerana kebenaran itu sendiri. Dan sesiapa yang terikat dengan pencarian demi kepentingan pencarian itu tidak akan berminat dengan hal-hal lain (yang tiada kepentingan). ${ }^{, 36}$

Daripada dua petikan kata Ibn al-Haytham dalam subtopik ini, ternyata bahawa pada pandangan beliau, objektiviti perlu berasaskan pembuktian yang sistematik, penghujahan yang teliti serta penyelidik perlu bersikap adil terhadap kebenaran objek kajian. Oleh yang demikian, Ibn al-Haytham menggunakan pendekatan penjelasan matematik bagi memecahkan keterbatasan kajian tabii alam yang dibuat dalam kajian-kajian ilmuwan Yunani silam. Misalnya dalam teori penglihatan, para ilmuwan Yunani terdahulu kebanyakan mencadangkan teori bersifat abstrak yang

35 Ibn al-Haytham, The Optics of Ibn al-Haytham, Book I-III: On Direct Vision, terj. Abdelhamid I. Sabra (London: Warburg Institute, University of London, 1989), 5-6.

36 Dipetik daripada Shlomo Pinès, The Collected Works of Shlomo Pines (Jldume II) (Jerusalem: The Magnes Press, The Hebrew University, 1986), 436. 
berasaskan pemikiran tanpa pembuktian yang jelas. ${ }^{37}$ Justeru, Ibn al-Haytham tampil dengan memperkenalkan teori intromisi (intromission theory) yang menepati kriteria matematik, fizik dan psikologi secara serentak. $^{38}$

\section{5) Kebenaran Tabii Boleh Dibuktikan dengan Matematik}

Ibn al-Haytham mempunyai minat yang mendalam terhadap ilmu matematik. ${ }^{39}$ Malah, beliau turut menyatakan bahawa dirinya termasuk dalam kalangan ahli matematik (așhāo al-ta'ālìm) ${ }^{40}$ Oleh itu, bagi Ibn al-Haytham, kebenaran dapat dicapai dengan kombinasi antara matematik dengan fenomena fizikal ${ }^{41}$. Perkara ini disebut secara jelas dalam korpus optiknya, Kitāb al-Manāzir dengan petikan:

"Subjek kami adalah kabur dan cara yang membawa kepada pengetahuan bersifat sukar; malahan, penyelidikan kami memerlukan gabungan sains tabii dan ilmu matematik." ${ }^{42}$

Matematik dalam pemikiran Ibn al-Haytham menjadi alat pembuktian terhadap fenomena yang dicerap. Hal ini menunjukkan keunikan yang terdapat dalam pemikiran Ibn alHaytham kerana kemampuannya mengaplikasikan ilmu matematik dalam ilmu tabii (tabīiyyah). ${ }^{43}$ Dalam Maqālah fì al-Tahlīl wa alTarkīb (Makalah berkenaan Analisis dan Sintesis), Ibn al-Haytham menyatakan bahawa matematik juga merupakan kaedah analisis yang bersifat umum dan ia sangat berguna untuk menyelesaikan masalah-masalah pembuktian yang lain. ${ }^{44}$

Misalnya, perkara ini dapat dilihat dalam kes kajian fenomena cahaya bulan dalam penulisannya yang bertajuk Maqālah fi Daw' al-Qamar (makalah tentang cahaya bulan).

37 Mohaini Mohamed, Great Muslim Mathematicians (Johor: Penerbit Universiti Teknologi Malaysia, 2000), 55.

38 Abdi Omar Shuriye, "Islamic Position on Physics with Reference to Ibn alHaytham," International Journal of Applied Science and Technology 1, no. 2 (2011): 61.

39 Steffens, Ibn al-Haytham: First Scientist, 37.

40 Roshdi Rashed, "A Polymath in the $10^{\text {th }}$ Century," 11-13.

41 Mohaini Mohamed, Great Muslim Mathematicians, 55.

42 Ibn al-Haytham, The Optics of Ibn al-Haytham, 4.

43 Muhammad Saud, The Scientific Method of Ibn al-Haytham, 22-25.

44 Mahmoud al-Deek, "Ibn al-Haitham: Master of Optics, Mathematics, Physics and Medicine," Al-Shindagah 61 (2004), http://www.alshindagah.com/novdec 2004/ibn.html, dicapai pada 15 Ogos 2013. 
Beliau menggunakan pembuktian matematik setelah mencerap tabii bulan yang akhirnya membawa kepada pengukuhan tauhid. ${ }^{45}$ Pengukuhan tauhid ini dapat dilihat melalui petikan kalam Allah SWT dalam ayat kelima daripada Surah Yunus yang dikemukakan pada awal penulisan beliau, diikuti dengan penjelasan geometrikal tentang pencahayaan bulan secara terperinci. ${ }^{46}$ Oleh yang demikian, jelaslah matematik antara alat penting yang sangat dititikberatkan oleh Ibn al-Haytham untuk membuktikan kebenaran dalam penyelidikan saintifiknya.

\section{6) Kebenaran Menuruti Sunnat Allāh}

Dalam menyatakan keharmonian perjalanan alam melalui ilmu matematik, Ibn al-Haytham berpegang dengan konsep alhatmiyyat al-ilmiyyah (determinisme saintifik). Ia merupakan suatu konsep kepatuhan fenomena alam semesta kepada suatu hukum yang harmoni atau disebut sebagai sunnat Allāh. Hukum inilah yang membolehkan cerapan dilakukan secara berulangulang kali. ${ }^{47}$ Perkara ini dapat dibuktikan melalui petikan kata beliau iaitu:

"Pencirian mata melalui sifat ini adalah salah satu perkara yang menunjukkan kebijaksanaan Maha Pencipta, besar kemuliaan-Nya, kehebatan penciptaan-Nya dengan rentak yang terhasil indah dan keteraturan alam yang telah mengatur alat penglihatan...."48

Ibn al-Haytham mengakui bahawa keteraturan proses penglihatan manusia sehinggakan pergerakan pantas mata apabila habuk memasukinya merupakan sunnat Alläh. Fitrah alam yang berbalik kepada undang-undang peraturan Allah SWT ini memudahkan beliau melakukan pencerapan terhadap fenomena

45 Abdul Ghafur Chaudhri, "Ibn al-Haitham: The Educational and Scientific Importance of His Writing," dalam Ibn al-Haitham: Proceedings of the Celebrations of $1000^{\text {th }}$ Anniversary Held Under the Auspices of Hamdard National Foundation, ed. Hakim Mohammad Said (Karachi: Hamdard Academy, 1969), 122.

${ }^{46}$ Ibn al-Haytham, The Light of the Moon, terj. Abdul Ghafur Chaudri, dalam Ibn al-Haitham: Proceedings of the Celebrations of $1000^{\text {th }}$ Anniversary Held Under the Auspices of Hamdard National Foundation, ed. Hakim Mohammad Said (Karachi: Hamdard Academy, 1969), 214

47 Mat Rofa Ismail, Mantik dalam Babak Pemikiran Ilmiah Tamadun Manusia (Kuala Lumpur: Dewan Bahasa dan Pustaka, 1997), 122.

48 Ibn al-Haytham, The Optics of Ibn al-Haytham, 103. 
tersebut. Perjalanan alam yang harmoni ini seterusnya membolehkan beliau menaakulnya berdasarkan penaakulan sebabakibat kerana ia merupakan sebahagian daripada sunnat Allăh. ${ }^{49}$ Justeru, pada pandangan Ibn al-Haytham, kebenaran seharusnya berada pada landasan undang-undang peraturan Allah SWT.

\section{Konsepsi Kebenaran Ibn al-Haytham dari Perspektif Falsafah Penyelidikan Islam}

Pada dasarnya, Ibn al-Haytham menekankan nilai kebenaran dalam penyelidikannya agar beliau dapat mencapai keredhaan Allah SWT atau marḍāt Allāh. ${ }^{50}$ Oleh itu, pendekatan saintifik diambil untuk meningkatkan keinginannya dalam mencari kebenaran. Dengan enam konsepsi kebenaran Ibn al-Haytham yang dikenal pasti, bahagian ini akan menganalisis konsepsikonsepsi tersebut berdasarkan falsafah penyelidikan Islam. Falsafah penyelidikan Islam yang dimaksudkan dalam makalah ini ialah penyelidikan yang berasaskan kepada teori ilmu atau epistemologi Islam dan juga tasawur Islam. ${ }^{51}$ Antara cendekiawan Muslim kontemporari yang membincangkan secara umum aspek falsafah penyelidikan Islam ini ialah Ismail al-Faruqi, Syed Muhammad Naquib al-Attas, Osman Bakar, Muhammad Mumtaz Ali, Louay Safi, Rosnani Hashim dan Muhammad Syukri Salleh.

Konsepsi pertama ialah Ibn al-Haytham meyakini kebenaran bersifat tunggal. Pada hakikatnya, perkara ini merupakan suatu fitrah yang dijelaskan di dalam al-Qur'an. Antara ayat al-Qur'an yang menyatakan maksud sebenar kebenaran ialah firman Allah SWT yang bermaksud:

"Kebenaran itu (wahai Muhammad) adalah datangnya dari Tuhanmu. Oleh itu, jangan sekali-kali engkau termasuk dalam golongan orang-orang yang ragu-ragu."

Daripada ayat ini, ketunggalan kebenaran mempunyai asasnya iaitu keimanan. Menurut Syed Muhammad Naquib alAttas, ${ }^{53}$ keimanan ini merangkumi kepercayaan yang setinggi-

\footnotetext{
49 Mat Rofa Ismail, Falsafah Sains Pendekatan Kualitatif, 185.

50 Ibn Abī Ușaybi'ah, 'Uyūn al-Anbā' fì Țabaqāt al-Ațibbā', 552.

51 Muhammad Syukri Salleh, "Kaedah Penyelidikan Berteraskan Islam: Keperluan, Kedudukan dan Hala Tuju," 136.

52 Al-Qur'an, Sūrah al-Baqarah, 2:147.

53 Syed Muhammad Naquib al-Attas, Islam and the Philosophy of Science, 2.
} 
tingginya bahawa Allah SWT adalah Tuhan yang Maha Esa, diyakini dengan persetujuan oleh hati dan tindakan anggota badan. Dalam kata lain, kebenaran yang bersifat tunggal ini datang daripada petunjuk melalui fakulti intuisi hati seseorang penyelidik dan diterjemahkan dalam bentuk penyelidikan. Justeru, kebenaran yang ingin dicapai oleh Ibn al-Haytham ini bersandarkan kepada keimanan yang membawa dirinya sebagai penyelidik kepada keyakinan yang tertinggi iaitu haq al-yaqin ${ }^{54}$

Konsepsi kedua menyentuh mengenai pandangan Ibn alHaytham bahawa kebenaran boleh datang dengan sikap skeptikal pada permulaan penyelidikan. Melalui Surah al-Baqarah, ayat 147 Allah SWT telah menjelaskan bahawa kebenaran bukanlah disebabkan oleh keraguan semata-mata, namun ia merupakan suatu petunjuk daripada-Nya. Pancaran petunjuk Ilahi inilah yang meneguhkan hati seseorang penyelidik daripada keraguan. Keraguan yang ingin dinyatakan oleh Ibn al-haythaam lebih merujuk kepada ketepatan kajian-kajian yang telah dilakukan oleh para penyelidik terdahulu. Malah beliau sendiri dengan jelas mengharapkan petunjuk daripada Allah SWT dalam melakukan kerja-kerja penyelidikannya seperti dalam kata-kata berikut:

"Sungguhpun semua ini (berdasarkan pencarian dan penyelidikan), kita tidak boleh melepaskan diri daripada kelemahan sebagai fitrahnya, namun kita perlu berusaha dengan kudrat yang dikurniakan. Daripada Allah SWT kita memohon pertolongan dalam setiap pekerjaan." 55

Kedudukan kaedah keraguan ini tidak mempunyai persamaan dengan kaedah keraguan yang difahami dari konteks penyelidikan Barat. Bagi aliran rasionalisme ${ }^{56}$ yang dipelopori oleh René

${ }^{54}$ Muhammad Syukri Salleh, "Kaedah Penyelidikan Berteraskan Islam: Keperluan, Kedudukan dan Hala Tuju," 137.

55 Ibn al-Haytham, The Optics of Ibn al-Haytham, 6.

56 Aliran rasionalisme mempercayai bahawa dengan penaakulan akal sahaja sesuatu ilmu tentang sesuatu kewujudan boleh didapati atau disebut sebagai $a$ priori. Bagi aliran ini, pemikiran secara rasional perlu dijadikan sebagai suatu kaedah dan minda logik sebagai proses menganalisis sesuatu ilmu pengetahuan. Lihat Laurence BonJour, Classic Problems and Contemporary Responses (United State of America: Rowman and Littlefield, 2002), 95; Ahmad Sunawari Long, Sejarah Falsafah Edisi Kedua (Selangor: Penerbit Universiti Kebangsaan Malaysia, 2008), 137. 
Descartes, ${ }^{57}$ keraguan atau skeptisisme merupakan satu kaedah yang dipercayai dapat membawa kepada kebenaran yang bersifat hakiki. ${ }^{5}$

Melalui konsepsi ketiga pula, Ibn al-Haytham berpandangan bahawa kebenaran tidak dapat disingkap dengan hanya bertaklid. Taklid tidak akan membawa kepada usaha mencari kebenaran. Malah, pandangan ini juga dipersetujui oleh al-Bīrūnī (973-1048 M), ilmuwan sezaman dengan Ibn al-Haytham. Al-Bīrūnī menegaskan bahawa penyelidik yang mengkaji kerana kebenaran akan mempamerkan banyak perbezaan yang ketara berbanding dengan penyelidik yang sekadar bertaklid. ${ }^{59}$

Selain itu, Ibn al-Haytham turut menjelaskan bahawa autoriti hanya boleh diberi kepada sumber wahyu dalam Islam iaitu alQur'an dan Hadith. Hal ini kerana wahyu merupakan sumber kebenaran mutlak yang memandu potensi akal seseorang penyelidik mencari kebenaran. ${ }^{60}$ Penegasan yang dinyatakan oleh Ibn al-Haytham iaitu 'kebenaran dicari kerana kebenaran' pada hakikatnya mempunyai implikasi yang sama sebagaimana pernyataan 'ibadah adalah untuk manusia yang beribadah itu sendiri'. Menurut Haron Din, Allah SWT tidak memerlukan ibadah seseorang manusia untuk menambah kehebatan diri-Nya kerana Dia-lah yang menciptakan manusia, tetapi ibadah dilakukan demi kebahagiaan dan manfaat diri pelakunya di dunia dan akhirat. ${ }^{61}$ Dalam pengertian yang sama, Allah SWT tidak berkehendak pada kebenaran yang dicari oleh seseorang pengkaji kerana Dia-lah pemilik kebenaran, ${ }^{62}$ tetapi usaha pencarian

57 Roger Scruton, Sejarah Ringkas Falsafah Moden daripada Descartes hingga Wittgenstein, terj. Dewan Bahasa dan Pustaka (Kuala Lumpur: Dewan Bahasa dan Pustaka, 1989), 30.

58 Syed Muhammad Naquib al-Attas, Islam and the Philosophy of Science, 8.

59 Abdul Latif Samian, "Pemalsuanisme dalam Falsafah Sains al-Biruni," Jurnal Pendidikan Islam 10, no. 4 (2004): 63.

${ }^{60}$ Osman Bakar, Tawhid and Science: Essays on the History and Philosophy of Islamic Science, 31.

61 Haron Din, Islam: Ibadah Pembina Tamadun Manusia (Kuala Lumpur: PTS Millenia, 2007), vii.

62 Allah SWT berfirman yang bermaksud: "Dan katakanlah (wahai Muhammad): 'Kebenaran itu adalah yang datang daripada Tuhan kamu. Maka sesiapa yang mahu beriman, hendaklah dia beriman dan sesiapa yang mahu kufur ingkar, biarlah dia mengingkarinya'..." (Al-Kahf 18:29). 
kebenaran akan memberi ketenangan hati dan manfaat kepada diri pengkaji tersebut.

Seterusnya, konsepsi Ibn al-Haytham yang keempat iaitu kebenaran ialah sesuatu yang bersifat objektif ini adalah hasil pemahaman terhadap konsep keadilan dalam Islam. Dalam alQur'an, Allah SWT berfirman yang bermaksud:

"... Hendaklah kamu berlaku adil (kepada sesiapa jua) kerana sikap adil itu lebih hampir kepada takwa dan bertakwalah kepada Allah, sesungguhnya Allah Maha Mengetahui dengan mendalam akan apa-apa yang kamu lakukan."

Oleh yang demikian, objektiviti yang dimaksudkan oleh Ibn al-Haytham selaras dengan konsep objektiviti dari perspektif Islam iaitu objek kajian perlu dinilai dengan sifat adil. ${ }^{64}$ Menurut Osman Bakar, ${ }^{65}$ konsep objektiviti dalam tradisi Islam adalah berasaskan kualiti penyelidikan yang adil dan neutral dengan kesepaduan dan kesedaran tauhid. Hal ini berbeza dari perspektif sarjana Barat daripada aliran positivisme. Menurut aliran ini, objektiviti perlulah bersifat bebas nilai atau tidak berat sebelah (unbiased). ${ }^{66}$ Penyelidik itu sendiri perlu bebas daripada apa-apa pegangan peribadinya termasuklah pegangan agama dan budaya sewaktu menyelidik. ${ }^{67}$ Malah, aliran ini juga menganggap bahawa setiap objek kajian, atau dalam konteks ilmu kemanusiaan objeknya ialah manusia, dilihat sebagai tidak ada nilai motivasi moral dan bersifat neutral. ${ }^{68}$ Pandangan seperti ini tidak bertepatan dengan falsafah penyelidikan Islam kerana manusia tidak bersifat bebas nilai. ${ }^{69}$ Justeru, seseorang penyelidik yang bersifat objektif perlu lengkap

63 Al-Mā'idah, 5:8.

64 Anis Malik Thoha, "Research Note: Objectivity and the Scientific Study of Religion," Intellectual Discourse 17, no. 1 (2009): 89.

65 Osman Bakar, Tawhid and Science: Essays on the History and Philosophy of Islamic Science, 9-10.

${ }^{66}$ Allen Rubin dan Earl R. Babbie, Research Methods for Social Work Seventh Edition (United State of America: Brooks/Cole, 2011), 100.

${ }^{67}$ William Lawrence Neuman, Social Research Methods, Qualitative and Quantitative Approaches, 571.

${ }^{68}$ F. R. Faridi, "Islamic Research Methodology: Some Reflections," dalam Research Methodology in Islamic Perspective, ed. Mohammed Muqim (Kuala Lumpur: Synergy Book International, 1999), 58.

69 Rosnani Hashim, "Falsafah Penyelidikan Pendidikan dari Perspektif Islam," Jurnal Pendidikan Islam 11, no. 1 (2004): 11. 
dengan bukti dan hujah yang kukuh serta berlaku adil terhadap objek kajiannya. ${ }^{70}$

Konsepsi kebenaran yang kelima menurut Ibn al-Haytham adalah kebenaran dalam kajian alam tabii dapat dibuktikan dengan ilmu matematik. Alam tabii yang dimaksudkan merangkumi alam jasmani dan alam rohani. ${ }^{71}$ Keyakinan beliau bahawa matematik mampu menjadi alat analisis kepada kajian alam tabii turut diyakini oleh al-Ghazālī. Dalam hal ini, al-Ghazālī mengkategorikan ilmu matematik sebagai ilmu bukan syariah yang terpuji kerana keaslian yang wujud pada asas ilmu tersebut. ${ }^{72}$ Pengukuhan akal dalam konteks mencari kebenaran adalah bersesuaian dengan kehendak Allah SWT yang menuntut manusia supaya berfikir. ${ }^{73}$ Malah, kedudukan matematik menurut majoriti ahli falsafah Muslim adalah sebagai ilmu perantara di antara ilmu tabii dengan ilmu metafizik. ${ }^{74}$ Perkara ini sepertimana yang dijelaskan oleh kumpulan ahli falsafah Muslim, Ikhwān al-Ṣāfā (Persaudaraan yang Suci) seperti berikut:

“... Matematik hanya jalan dan cara untuk menyampaikan ilmu-ilmu tabii. Adapun tujuan ilmu tabii ialah pendakiannya kepada ilmu-ilmu metafizik, yakni tujuan tertinggi para hukamā', jalan pengakhiran hakikat ilmu., 75

Akhir sekali, konsepsi keenam Ibn al-Haytham ialah kebenaran sentiasa mematuhi sunnat Allāh. Kejadian manusia dan alam semesta pada hakikatnya adalah sentiasa mengikuti satu peraturan yang konsisten daripada Allah SWT. Oleh kerana itu, perhubungan yang konsisten ini dapat dihubungkan dengan

${ }^{70}$ Khalif Muammar A. Harris dan Adibah Mukhtar, "Objektiviti Menurut Perspektif Islam” (makalah, Seminar Pengurusan Pembangunan Islam II: Kaedah Penyelidikan Berteraskan Islam, Universiti Sains Malaysia, 6 Februari 2008.

71 Frithjof Schuon, Form and Substance in the Religions (Pentagon: World Wisdom, 2002), 54.

72 Al-Ghazāî̀, Ihyā' 'Ulūm al-Dīn (Revival of Religious Learnings, Vol. 1), terj. Fazl-ul-Karim (Karachi: Darul-Ishaat, 1993), 31 \& 57.

73 Osman Bakar, Tawhid and Science: Essays on the History and Philosophy of Islamic Science, 24.

74 Mat Rofa Ismail, Mantik dalam Babak Pemikiran Ilmiah Tamadun Manusia, 84.

75 Dipetik daripada Mat Rofa Ismail, Mantik dalam Babak Pemikiran Ilmiah Tamadun Manusia, 85. 
penaakulan sebab-akibat. ${ }^{76}$ Walau bagaimanapun, prinsip sebabakibat dari perspektif Barat diletakkan sebagai suatu perhubungan yang wajib di antara perkara-perkara yang empirikal sahaja. ${ }^{77}$ Namun, sarjana Muslim silam seperti al-Ghazālī dan Ibn Rushd bersependapat bahawa kehendak Allah SWT sentiasa mempunyai hubungan dengan konsep kebiasaan ('âdah) yang diperkenalkan al-Ghazālī, mahupun prinsip sebab-akibat yang dipertahankan Ibn Rushd. $^{78}$

Dengan yang demikian, kefahaman mengenai konsep sunnat Allāh ini adalah bersumberkan wahyu Ilahi iaitu ayat-ayat alQur'an. ${ }^{79}$ Oleh itu, kebenaran yang diselidiki pada awalnya bermula dengan memahami kalam Tuhan dan berakhir pula dengan mengenali Tuhan. ${ }^{80}$ Menurut Muhammad Mumtaz Ali, ${ }^{81}$ penyelidikan saintifik dalam Islam seharusnya membawa penyelidik mengenali dan mengakui Allah SWT sebagai Pencipta dan Pemelihara manusia dan alam semesta. Justeru, dapat disimpulkan bahawa matlamat Ibn al-Haytham untuk mendapat keredhaan Allah SWT dapat diperoleh dengan konsepsi kebenaran yang berteraskan tauhid yang menjadi tunjang utama penyelidikan saintifiknya.

\section{Penutup}

Berdasarkan perbincangan dalam dua bahagian sebelum ini, makalah ini telah menjawab persoalan-persoalan yang timbul. Pertama, Ibn al-Haytham berpegang kepada sekurang-kurangnya enam konsepsi kebenaran iaitu pertama, kebenaran bersifat tunggal; kedua, kebenaran tidak dapat disingkap dengan taklid; ketiga, kebenaran merupakan petunjuk yang boleh bermula dengan sikap skeptik; keempat, kebenaran bersifat objektif; kelima,

${ }^{76}$ International Institute of Islamic Thought, Pengislaman Ilmu, terj. Mustafa Kasim (Kuala Lumpur: Dewan Bahasa dan Pustaka, 2009), 35.

77 Jonathan H. Turner, "In Defense of Positivism", Sociological Theory 3, no. 2 (1985): 26.

78 Louay Safi, Asas Ilmu Pengetahuan, terj. Nur Hadi Ihsan (Petaling Jaya: Thinker's Library, 1998), 199-213.

79 Mohd Yusof Othman, Sains, Masyarakat dan Agama (Kuala Lumpur: Utusan Publications \& Distributors, 2009), 216.

80 International Institute of Islamic Thought, Pengislaman Ilmu, 36.

${ }^{81}$ Muhammed Mumtaz Ali, Islamic and Western Philosophy of Knowledge: Contemporary Methodological Issues (Petaling Jaya: Pelanduk Publications, 1994), 89. 
kebenaran kajian alam tabii boleh berwasilahkan ilmu matematik; dan keenam, kebenaran adalah berasaskan sunnat Allāh. Kedua, daripada analisis keenam-enam konsepsi kebenaran tersebut, jelas bahawa penyelidikan saintifik Ibn al-Haytham berteraskan falsafah penyelidikan Islam yang berasaskan tauhid kepada Allah SWT dan wahyu-Nya.

\section{Bibliografi}

Abdul Latif Samian. "Pemalsuanisme dalam Falsafah Sains alBiruni," Jurnal Pendidikan Islam 10, no. 4 (2004): 57-76.

Abdul Rahman Abdullah. Wacana Falsafah Sains: Sejarah dan Pemikiran. Pulau Pinang: Pusat Kajian Pengurusan Pembangunan Islam Universiti Sains Malaysia, 2010.

Abdullah Muhammad Basmeih. Tafsir Pimpinan Ar-Rahman Kepada Pengertian Al-Qur'an, ed. Muhammad Noor Haji Ibrahim. Kuala Lumpur: Darul Fikir dengan izin dan kawalan Jabatan Kemajuan Islam Malaysia, 2001.

Ahmad Mahdzan Ayob. Kaedah Penyelidikan Sosioekonomi. Kuala Lumpur: Dewan Bahasa dan Pustaka, 2007.

Ahmad Sunawari Long. Sejarah Falsafah Edisi Kedua. Selangor: Penerbit Universiti Kebangsaan Malaysia, 2008.

Al-Jabri, Mohammed Abed. The Formation of Arab Reason: Text, Tradition and the Construction of Modernity in the Arab World. New York: I.B Tauris \& Co., 2011.

Al-Deek, Mahmoud. "Ibn al-Haitham: Master of Optics, Mathematics, Physics and Medicine," laman sesawang $\mathrm{Al}$ Shindagah 61, http://www.alshindagah.com/novdec2004/ibn.html, dicapai pada 15 Ogos 2013.

BonJour, L., Classic Problems and Contemporary Responses. United State of America: Rowman and Littlefield, 2002.

Chaudhri, Abdul Ghafur. "Ibn al-Haitham: The Educational and Scientific Importance of His Writing," dlm. Ibn al-Haitham: Proceedings of the Celebrations of $1000^{\text {th }}$ Anniversary Held Under the Auspices of Hamdard National Foundation, ed. Hakim Mohammad Said. Karachi: Hamdard Academy, 1969.

F. R. Faridi. "Islamic Research Methodology: Some Reflections," $\mathrm{dlm}$. Research Methodology in Islamic Perspective, ed. 
Mohammed Muqim. Kuala Lumpur: Synergy Book International, 1999.

Gorini, R.. "Al-Haytham the Man of Experience: First Steps in the Science of Vision," Journal of the International Society for the History of Islamic Medicine 2, no. 4 (2003): 53-55.

Haron Din. Islam: Ibadah Pembina Tamadun Manusia. Kuala Lumpur: PTS Millenia, 2007.

Harun Nasution. Teologi Islam: Aliran-Aliran Sejarah Analisa Perbandingan. Jakarta: Penerbit Universits Indonesia, 1983.

Heinen, A. M. "Al-Biruni and al-Haytham: A Comparative Study of Scientific Method," dlm. Al-Bīrūnī Commemorative Volume: Proceedings of the International Congress Held in Pakistan on the Occasion of Millenary of Abū Raīhān Muhammad ibn Ahmmad al-Bīrūnī, ed. Hakim Mohammed Said. Karachi: Hamdard Academy, 1973.

Ibn Abī Ușaybi'ah, Aḥmad ibn Qasim. 'Uyūn al-Anbā' fì Tabaqāt al-Ațibbā'. Beirut: Dār Maktabah al-Ḥayah, 1965.

Ibn al-Haytham, al-Hasan bin al-Hasan, The Light of the Moon, terj. Abdul Ghafur Chaudri, dlm. Ibn al-Haitham: Proceedings of the Celebrations of $1000^{\text {th }}$ Anniversary Held Under the Auspices of Hamdard National Foundation, ed. Hakim Mohammad Said. Karachi: Hamdard Academy, 1969.

Ibn al-Haytham, al-Hasan bin al-Hasan, The Optics of Ibn alHaytham, Book I-III: On Direct Vision, terj. Abdelhamid I. Sabra. London: Warburg Institute, University of London, 1989.

International Institute of Islamic Thought, Pengislaman Ilmu, terj. Mustafa Kasim. Kuala Lumpur: Dewan Bahasa dan Pustaka, 2009.

Kennedy, A., Radach, R., Heller, D. \& Pynte, J. Reading as a Perceptual Process. Oxford: Elsevier Science, 2000.

Khalif Muammar A. Harris dan Adibah Mukhtar. "Objektiviti Menurut Perspektif Islam," Seminar Pengurusan Pembangunan Islam II: Kaedah Penyelidikan Berteraskan Islam. Universiti Sains Malaysia, 6 Februari 2008.

Louay Safi. Asas Ilmu Pengetahuan, terj. Nur Hadi Ihsan. Selangor: Thinker's Library, 1998.

Mat Rofa Ismail. Mantik dalam Babak Pemikiran Ilmiah Tamadun Manusia. Kuala Lumpur: Dewan Bahasa dan Pustaka, 1997. 
Falsafah Sains Pendekatan Kualitatif. Kuala

Lumpur: Dewan Bahasa dan Pustaka, 2006.

Mohaini Mohamed. Great Muslim Mathematicians. Johor: Penerbit Universiti Teknologi Malaysia, 2000.

Mohd Yusof Othman. Sains, Masyarakat dan Agama. Kuala Lumpur: Utusan Publications \& Distributors, 2009.

Muhammad Abu Zahrah. Aliran Politik dan 'Aqidah dalam Islam, terj. Abd. Rahman Dahlan \& Ahmad Qarib. Jakarta: Logos, 1996.

Muhammad bin Muhammad al-Ghazali. Penyelamat dari Kesesatan, terj. Abdulfatah Haron Ibrahim. Kuala Lumpur: Dewan Bahasa dan Pustaka, 1991.

Muhammad bin Muhammad al-Ghazali. Ihya' 'Ulum al-Din (Revival of Religious Learnings Vol. 1), terj. Fazl-ul-Karim. Karachi: Darul-Ishaat, 1993.

Muhammad Saud. The Scientific Method of Ibn al-Haytham. Islamabad: Islamic Research Institute, 1990.

Muhammad Syukri Salleh. "Kaedah Penyelidikan Berteraskan Islam: Keperluan, Kedudukan dan Hala Tuju," Pemikir, no. 54 (2008): 133-164.

Muhammed Mumtaz Ali. Islamic and Western Philosophy of Knowledge: Contemporary Methodological Issues. Selangor: Pelanduk Publications, 1994.

Neuman, W. L. Social Research Methods, Qualitative and Quantitative Approaches Seventh Edition. Boston: Pearson Education, 2011.

Osman Bakar. Tawhid and Science: Essays on the History and Philosophy of Islamic Science. Pulau Pinang: Secretariat for Islamic Philosophy and Science, 1991.

Pinès, S. The Collected Works of Shlomo Pines Volume II. Jerusalem: The Magnes Press The Hebrew University, 1986.

Rashed, Roshdi. "A Polymath in the $10^{\text {th }}$ Century," Science 297 (2002): 773.

Rashed, Roshdi. "The Celestial Kinematics of Ibn al-Haytham," Arabic Sciences and Philosophy 17 (2007): 7-55.

Rosnani Hashim. "Falsafah Penyelidikan Pendidikan dari Perspektif Islam," Jurnal Pendidikan Islam 11, no. 1 (2004): 116. 
Rubin, A. \& Babbie, E. R. Research Methods for Social Work Seventh Edition. United State of America: Brooks/Cole, 2011. Saliba, G. Islamic Science and the Making of European Renaissance. Cambridge, Mass.: The MIT Press, 2007.

Schuon, F. Form and Substance in the Religions. Pentagon: World Wisdom, 2002.

Scruton, Roger. Sejarah Ringkas Falsafah Moden daripada Descartes hingga Wittgenstein, terj. Dewan Bahasa dan Pustaka. Kuala Lumpur: Dewan Bahasa dan Pustaka, 1989.

Selamat Amir, Mohd Murshidi Mohd Noor dan Ahmad Bazli Ahmad Hilmi. "Aplikasi Elemen Saintifik dalam Tafsir alQur'an: Satu Pengamatan Awal Terhadap Manhaj Zaghlūl elNajjār dalam 'Tafsīr al-Ayah al-Kawnīyyah fi al-Qur'ān alKarīm,' Al-Bayan 10, no. 2 (2012): 49-68.

Seyyed Hossein Nasr. Knowledge and the Sacred. Albany: State University of New York, 1989.

Shaharir Mohamad Zain. Pengenalan Sejarah dan Falsafah Sains. Bangi: Penerbit Universiti Kebangsaan Malaysia, 2000.

Shahir Akram Hassan. Penerapan Kaedah Pengumpulan Hadith dalam Penyelidikan. Kuala Lumpur: Dewan Bahasa dan Pustaka, 2013.

Sobhi Rayan. "Islamic Philosophy of Education," International Journal of Humanities and Social Science 2, no. 19 (2012): 150156.

Steffens, B. Ibn al-Haytham: First Scientist: Greensboro: N. C. Morgan Reynolds Publications, 2007.

Shuriye, Abdi Omar. "Islamic Position on Physics with Reference to Ibn al-Haytham," International Journal of Applied Science and Technology 1, no. 2 (2011): 59-64.

Sulaiman Noordin. "Sains, Falsafah dan Islam," dlm. Siri Wacana Sejarah dan Falsafah Sains Jilid I, ed. Mohd Yusof Othman. Kuala Lumpur: Dewan Bahasa dan Pustaka, 1992.

Syed Muhammad Naquib al-Attas. Islam and the Philosophy of Science. Kuala Lumpur: International Institute of Islamic Thought and Civilization, 1989.

Talib Samat. 99 Nama Allah Tersohor: Khasiat dan Cara Beramal. Kuala Lumpur: Utusan Publications and Distributors, 2004. 
Thoha, Anis Malik. "Research Note: Objectivity and the Scientific Study of Religion," Intellectual Discourse 17, no. 1 (2009): 8392.

Turner, J. H. "In Defense of Positivism," Sociological Theory 3, no. 2 (1985): 24-30.

Ziauddin Sardar. Hujah Sains Islam, terj. Abdul Latif Samian. Kuala Lumpur: Dewan Bahasa dan Pustaka, 1992. 
Syahmir, Konsepsi Kebenaran dalam Penyelidikan Saintifik 